Arab World English Journal (AWEJ) Special Issue on Covid 19 Challenges April 2021

DOI: https://dx.doi.org/10.24093/awej/covid.9

\title{
Developing Elementary EFL Learners' Procedural Knowledge and Strategic Awareness in Reading Classes during the Covid-19 Pandemic: Algerian Teachers' Challenges
}

\author{
Kamila AMMOUR \\ Department of English, Faculty of Letters and Languages \\ Mouloud Mammeri University, \\ Tizi-Ouzou, Algeria \\ Email: kamila.ammour@ummto.dz
}

Recived: $3 / 6 / 2021$

Accepted: 4/9/2021

Published:4/26/2021

\begin{abstract}
The Covid-19 pandemic has affected educational systems worldwide, leading some scholars to scrutinise the consequences of lockdown and school closure on learners' learning habits and teachers' teaching practices. In this regard, this paper aims to explore the teachers' challenges while implementing a reading strategy-based instruction for beginners during the Covid-19 pandemic, taking the Algerian middle schools as a case in point. It highlights the difficulties to achieving quality in developing learners' procedural knowledge and strategic awareness in EFL reading classes. The leading approach to the issue is the interactive approach. To attain the objective of the research, the qualitative method was adopted. Classroom observation and structured interviews were used to collect data. The population targeted was composed of 20 teachers from 16 middle schools in Tizi-Ouzou. The collected data were subjected to qualitative content analysis. The results of the study reveal that most teachers are aware of the importance of reading strategy-based instruction. However, they do not teach them systematically or consistently. Indeed, lack of targeted teacher training, time constraints, and disregard of metacognitive instruction are likely to be obstacles to the efficient implementation of reading strategy-instruction. Furthermore, the Covid-19 pandemic has thrown up several psychological and cognitive learners' difficulties, including decreased motivation and lack of cognitive focus, making the teaching process more challenging. The results imply a need for a revision of teachers' professional development programs and a re-consideration of the elementary EFL courses.
\end{abstract}

Keywords: Algerian EFL learners, the Covid-19 pandemic, elementary reading classes, procedural knowledge, strategic awareness, teachers' challenges

Cite as: AMMOUR, K. (2021). Developing Elementary EFL Learners' Procedural Knowledge and Strategic Awareness in Reading Classes during the Covid-19 Pandemic: Algerian Teachers' Challenges. Arab World English Journal (AWEJ) Special Issue on Covid 19 Challenges (1) 127135. DOI: https://dx.doi.org/10.24093/awej/covid.9 


\section{Arab World English Journal (AWEJ) Special Issue on Covid 19 Challenges April 2021}

Developing Elementary EFL Learners' Procedural Knowledge

AMMOUR

\section{Introduction}

Due to the spread of the Covid-19 pandemic, the development of learners' procedural knowledge and strategic awareness becomes one of the urgent educational issues in EFL instruction. As a result of schools shut for months, it becomes crucial to direct language pedagogy towards developing learners' autonomy. This can be achieved through developing appropriate reading strategies. Strategy-based models aim at, among other things, increasing learners' strategic awareness and developing their procedural knowledge. Indeed, previous studies established a correlation between strategy-instruction and learners' achievement (e.g., Pessley, 2002; Kucer, 2005).

Since the early 1970s, reading instruction has become the focus of many studies, and the reading skill an essential component of any reading program. Yet, researchers did not agree upon an adequate way of teaching EFL reading that helps learners become independent readers. Because successful reading requires both bottom-up and top-down processing, a balanced reading instruction approach is suggested (Birch, 2002). It draws on the merits of the interactive approach that perceives reading as an individual interactive process depending mainly on a myriad of factors (Smith, 1988 as cited in Emerald, 1991).

Teachers, among other factors, play a vital role in the creation of a supportive learning environment. Their main task is to facilitate the learning process. In the context of EFL reading instruction, they have a tremendous responsibility for providing appropriate language instruction to enable the learners to become lifelong learners. Indeed, "the great majority of students in the world learn language through the mediation of a teacher" (Hutchinson \&Waters, 1987, p.82). The teachers' role is to find a stratagem for creative use of the various reading activities and the available materials. More to the point, teachers' role is to help their learners develop the procedural knowledge needed to interact with multiple types of texts.

At the end of 2019, the whole world was shaken by the spread of Covid-19, leading to many distinctive education changes. In the Algerian context, higher education institutions adopted the e-learning model, whereby teaching was undertaken on digital platforms. However, primary, middle, and secondary schools learners were out of their classrooms for more than five months due to the lockdown. By the beginning of September 2021, schools in different parts of the country started to re-open gradually. The lockdown has, undoubtedly, impacted on learners at the psychological and cognitive levels, making the task of teachers more challenging. Accordingly, this research addresses the issue of teachers' challenges by attempting to answer two research questions

- How do teachers handle EFL reading strategies instruction at the elementary level?

- What are the challenges facing Algerian EFL teachers while developing learners' procedural knowledge and strategic awareness during the Covid-19 pandemic?

The overall aim of this study is to highlight some of the difficulties faced by middle school teachers as they struggle to integrate reading strategies instruction into their reading classes during the Covid-19 pandemic. It strives to identify their practices while teaching procedural knowledge and developing strategic awareness among elementary EFL learners. 
Arab World English Journal (AWEJ) Special Issue on Covid 19 Challenges April 2021

Developing Elementary EFL Learners' Procedural Knowledge

AMMOUR

\section{Literature Review}

\section{EFL Instruction during the Covid-19 Pandemic in Algeria}

The unexpected lockdown imposed by the Algerian authorities since mid-Mach 2020 led to the closure of schools and universities. Higher education institutions shifted to distance learning to resume the academic year. However, the ministry of education asked the various authorities to cancel the last year term; they suggested some alternative teaching methods for the candidates for the baccalaureate exam. As a result, different pupils from different levels found themselves out of school for more than six months.

Some Algerian scholars endeavoured into research to scrutinize the impact of the Covid19 pandemic and the lockdown on teaching and learning. Benkhider \& Kherbachi (2020), for instance, examined the new learning habits of Algerian learners to maintain remote learning. A correlation study was conducted to depict the different factors that influence students' learning habits. The results revealed that "digital technologies used awareness of self-learning progress, and knowledge needed to maintain environmental development and the format of digital resources provided" (p.425) were the most influencing factors.

In another study, Chelghoum \& Chelghoum (2020) investigated the most common difficulties faced by university teachers in online teaching. An online questionnaire was addressed to 387 university teachers in Algeria, from different disciplines, through their email addresses. The results revealed that teachers face "many problems especially internet accessibility and students' motivation" (p. 118).

In the studies mentioned above, a variety of issues are addressed in terms of practices, perceptions, or challenges. Nevertheless, it is worth noting that all the published studies so far in the Algerian context focus on virtual learning in higher education contexts. The present study, however, finds its niche in the challenges of teachers at the elementary level in a real context after the re-opening of schools.

\section{Defining Reading}

The goals of current reading research are twofold. First, it seeks to gain a better understanding of the nature of the process. Second, it strives to design effective methods for reading instruction. In an attempt at providing a systematic definition of reading, researchers elaborated various reading models that describe what happens in the readers' eyes and mind during the reading process. Three models are to be found in the literature: bottom-up, top-down, and interactive.

Developed during the 1940s and the 1950s, bottom-up models describe the reading process in terms of serial steps in which "the direction of processing is from bottom-level features of text to higher levels" (Davies, 1995, p. 169). Stated differently, the bottom-up models perceive reading as a decoding process that involves reconstructing the author's meaning via recognising the letters and words (Carrel, Devine, \& Eskey, 1988).

Developed within psycholinguistics, top-down models of the reading process define reading as a psycho-cognitive process. To these models, the reader, rather than the text, is at the heart of the reading process. They emphasise the reader's interpretation of texts by guessing the 


\section{Arab World English Journal (AWEJ) Special Issue on Covid 19 Challenges April 2021}

Developing Elementary EFL Learners' Procedural Knowledge

AMMOUR

meaning based on their background knowledge. The best-known top-down models of the reading process are suggested by Goodman (1970) and Smith (1971).

As regards the interactive model, which is also known as the interactive approach, it focuses on the various kinds of knowledge that readers use to understand texts. The roots of this approach go back to a theory developed by Rumelhart in the late 1970s. He defined reading as a bi-directional perceptive and cognitive process that involves the reader and the text alike (Davies, 1995). In simpler words, getting meaning from a text results from the interaction between the information presented in the text and the specificities of readers' background knowledge. According to the interactive approach, texts do not "contain meaning"; they, rather, have "potential for meaning" (Wallas, 1992, p. 39).

\section{Developing Learners' Procedural Knowledge and Strategic Awareness}

At the heart of the interactive approach lies the principle of text-processing. This suggests that meaning construction is the result of the interaction of the reader with the text. Based on the latter theory, the pedagogical focus shifts from the text to the interactive process between the text and the reader. Some kind of processing mechanism is crucial to the achievement of this interaction. The processing component, also known as procedural knowledge, consists of a variety of strategies and skills. They allow the reader to take the text as a source of information, and drawing on their background knowledge as another source to make sense of what is on the printed page (Birch, 2002). Theorists and practitioners believe that teaching reading strategies for text processing leads to literacy development (Carrell et al., 1988).

As far as strategic awareness is concerned, it relates to learners' consciousness about their cognitive reading strategies together with the way they can regulate their thinking. According to Carrell et al. (1988), developing learners' strategic awareness is of paramount importance because they need to know the kind of reading and thinking required to understand different types of texts.

\section{Methods \\ Participants}

The targeted population involves twenty Middle School English language teachers working in sixteen schools located in urban and rural areas of Tizi-Ouzou, a medium-size town, $100 \mathrm{Km}$ from Algiers, Algeria. Due to the impracticality of observing all the teachers in their classrooms, a representative sample is selected through convenience sampling. The latter is a practical sampling strategy as the researcher chooses a group of individuals willing to participate in the study. Hence, volunteered teachers have been interviewed and observed on the basis of their availability. Accordingly, the present study is an exploratory case study. In this context, Bell (1987) states that case studies give "an opportunity for one aspect of a problem to be studied in some depth within a limited time scale" (p. 06).

\section{Instruments}

Since the objective of this study is to explore the challenges and the techniques used by teachers in EFL elementary reading classes, classroom observation, together with structured interviews were, used to collect appropriate data. Classroom observation is "a technique that can often reveal characteristics of groups of individuals which would have been impossible to 


\section{Arab World English Journal (AWEJ) Special Issue on Covid 19 Challenges April 2021}

Developing Elementary EFL Learners' Procedural Knowledge

AMMOUR

discover by other means" (Bell, 1987, p. 88). The aim of its use is to tap as fully as possible the teachers' daily instructional practices as part of strategy-based instruction. An observation scheme is designed by the researcher to make the observation systematic. A total of 20 reading classes were observed on a one-time basis for a sixty-minute period. The majority of the observations were recorded on a videotape. However, because some teachers refused to be filmed, written field notes were collected by the researcher during the observations.

Concerning the structured interview, it is a common research technique in reading research. It aims to gather the informants' opinions and experiences within a real context. It is composed of five items devoted to the teachers' perceptions of EFL reading instruction and their daily difficulties.

\section{Data Analysis}

The interviews and classroom observations of teachers in their reading classes have provided us in-depth descriptions of their practices. The data analysis tool employed is Qualitative Content Analysis. The latter is a well-known flexible technique used to analyse qualitative data to interpret meaning. Its core principle is "to conceptualise the process of assigning categories to text passages as a qualitative interpretive act" (Mayring, 2014, p.10). It suggests identifying predetermined coding categories by using existing theoretical backgrounds. After scrutinising the observational transcripts together with the interviews with teachers, issues for discussion emerged.

\section{Findings and Discussion \\ Teachers' Practices}

When asked about the objective of reading classes, most of the interviewed teachers have shown their awareness about the importance of reading-strategies instruction. However, they do believe that the teaching environment is hardly auspicious. The lockdown of learners for weeks led to the development of a new conception of learning. Their only objective, as learners, according to one interviewed teacher, is to pass first time as she stated:

I am disappointed at the learners' attitude towards English subject. They are only interested in marks, and how to pass [...] learners perceive reading instruction as a process of vocabulary building, grammar construction, and sentence analysis [...] rare is the focus on comprehension, information gathering, or reading strategies development.

Reading instruction requires a particular set of teaching techniques that aim at developing learners' strategies. Any professional teacher is supposed to receive training on those techniques. Yet, the classroom observations have shown that there is little use and, sometimes, a total absence of the reading teaching techniques credited by solid theoretical or empirical support in the literature. In fact, the result reached is consistent with some empirical researches indicating a lack of connection between strategy-instruction models and classroom practices (Pressley, 2002). Some reasons for this may include the fact that the Algerian middle school teachers attached more importance to grammar teaching. They tended to emphasise teaching reading as a means to practise the language. Oppositely, they neglect developing reading strategies and skills. The reading instruction model followed by the observed teachers is 'the traditional comprehensiontesting model'. According to Anderson (1999), the classroom, in this model, is teacher- 


\section{Arab World English Journal (AWEJ) Special Issue on Covid 19 Challenges April 2021}

Developing Elementary EFL Learners' Procedural Knowledge

AMMOUR

dominated, and the role of learners is to receive the instruction in order to complete comprehension-testing activities passively.

During the observation sessions, it has been noticed by the researcher that most of the participants started their reading classes by a pre-reading stage. Its aim is to activate learners' schematic knowledge and ensure purposeful reading. However, it is worth noting that, if it is not well implemented, the pre-reading is not likely to help learners develop their reading strategies.

In most of the observed sessions, when teachers started with a pre-reading phase, it seems at first sight that learners would make some predictions about the content of the text they are about to read, but teachers did not link the first phase to the second one. Furthermore, even though teachers succeeded in activating the learners' background knowledge, their procedure failed at getting the learners involved in the text since they did not state a purpose for reading. Given that in real life, we usually have a purpose for reading; we read because we want to, it is crucial to set out some reason for reading. The learners should go beyond the idea of reading a text because the teacher instructs them to do it; or simply because it is there and it is the next activity to perform. One can come to the conclusion, then, that the teachers are acquainted with the three-phase procedure without some practical orientations about applying it in the classroom. Teachers' practices are partially, due to their unawareness about how to put into practice their theoretical background. By the same token, it is worth mentioning that due to the spread of Covid-19, the number of classes is reduced, and the time allotted to various school subjects is limited. These factors are likely to make learners less motivated and teaching practices more challenging. Likewise, one of the findings of Chelghoum \& Chelghoum (2020) regarding the challenges of Algerian university teachers is the lack of motivation among students as a consequence of lockdown.

\section{Strategic Awareness}

A significant finding of the classroom observation is the poor development of strategic reading among the learners. Evidence of this problem includes learners' inability to read and comprehend the activities' instructions. One of the causes identified in the present investigation, which is consistent with some educational scholars' findings, is the lack of metacognitive instruction. This result is in line with the conclusion reached by Benkhider \& Kherbachi (2020), who established a correlation between metacognitive awareness and learners' achievement. In the same vein, Anderson (1991) claims that successful second language reading comprehension is not a matter of knowing what strategy to use, but the reader must also know to use it successfully and know how to orchestrate its use with other strategies. It is not sufficient to know about strategies, but a reader must also be able to apply them strategically.

(as cited in Carrell, 1998, p. 07)

In order to gain a good understanding of texts, strategic readers reflect on what they are doing while reading. In other terms, they constantly think about the strategies they need to interact with the text.

Strategic awareness is an integral part of success in learning how to use reading strategies. Teachers' explanations include "information about what the strategy is, why and how it should be learned, where and when to use the strategy, as well as how to evaluate the use of the strategy" (Anderson, 1991, p. 470). However, the classroom observations demonstrated that most 


\section{Arab World English Journal (AWEJ) Special Issue on Covid 19 Challenges April 2021}

Developing Elementary EFL Learners' Procedural Knowledge

AMMOUR

teachers did not use strategy terms, did not inform the learners about the lesson objective, did not discuss the usefulness of strategies, and did not model them. Besides, they neither explained the reasoning behind their thinking nor encouraged them to select the needed strategies to facilitate the decoding and understanding of texts.

\section{Teachers' Difficulties}

Many studies in the literature testify to the fact that implementing reading strategies instruction is challenging (Pressley, 2002). Time-consuming is one of the difficulties experienced by the Algerian EFL teachers; they keep struggling to complete the course. When asked about the difficulties encountered, one respondent pointed out: "am not satisfied with the way we are teaching [...]I don't have enough time to cover the material[...] I can't let my learners think for a long time...I don't have enough time to work with each learner”. Teaching reading strategies is a complex and long-term process that needs a long period of time for teachers and learners alike.

The interviewed teachers reported the increasing demotivation noticed among their learners. The psychological impact of the pandemic seems to be worse than the physiological one. Besides, it was noticed that learners lack some cognitive focus during the different classes. One of the teachers acknowledged that "such environment is not conducive to effective learning and much less to efficient reading strategies instruction".

Teachers today are dealing with a multitude of challenges that they have never faced before. They do not feel appropriately prepared to meet the new roles assigned to them regarding the available resources. Perhaps more disappointing is the lack of professional support mechanisms that may foster the implementation of the new learner-centred teaching paradigm. Additionally, the teachers have to adapt the new teaching paradigms to the teaching conditions of the Algerian middle school. They made it clear that they needed extensive professional development support for that. The majority of the respondents stressed the need for adequate training to cope with the latest teaching paradigms.

Consistent with the conclusions reached in the previous studies, though in different contexts, lack of professional support and learners' decrease motivation are depicted as significant problems for teachers. Nevertheless, unlike the previous studies (Benkhider \& Khebachi , 2020; Chelghoum \& Chelghoum, 2020) that stressed technical issues related to the use of digital devices in distance learning, the present study highlights daily challenges of teachers in face-to-face teaching, namely time constraints and lack of learners' cognitive focus.

\section{Teachers' Commitment}

The results reveal that while some teachers exclude reading-strategy instruction from their classes, others, mainly newly recruited teachers, are convinced that the pedagogical benefits of strategy-instruction are worth the challenges and the difficulties that they confront while implementing them. Through the various observations, it was noticed that some enthusiastic teachers expressed the desire to be more involved. One teacher showed her will to implement the strategy-instruction model faithfully. She held a quite constructivist view to reading instruction: "I try to depict some knowledge that my learners have experienced in their lives to relate it to the text $[\ldots]$ then I model for the way to follow in order to make their reading more efficient". 
Arab World English Journal (AWEJ) Special Issue on Covid 19 Challenges April 2021

Developing Elementary EFL Learners' Procedural Knowledge

AMMOUR

Her performance has shown her degree of commitment to support independent-learner learning through strategy instruction. However, when asked about theory, she said that more explanations and modelling in in-service training courses were needed. What helps this teacher succeed in her job is her conviction that, as Brown (2001) puts it, "one of the most invigorating things about teaching is that you never stop learning" (p. 426).

\section{Conclusion}

This research article has explored the Algerian teachers' challenges in EFL elementary reading classes during the Covid-19 pandemic. In conclusion, one can safely assert that the teachers' practices are not consistent with the pedagogical philosophy embodied in reading strategy instruction due to several factors. Indeed, the findings showed that some of these factors include the working environment, time constraints, disregard of metacognitive instruction, lack of teacher training together with learners' increasing demotivation, and lack of cognitive focus. Therefore, middle school teachers need more theoretical background and practical orientations to get involved in the new teaching paradigms and cope with the new conditions caused by the spread of the Covid-19 pandemic.

A limitation of this study is that the informants' number was relatively small, and much focus was put on teachers. It would be interesting to conduct other studies to explore learners' perceptions and challenges to get a broader look of the state of the art in educational issues during the outbreak of the Covid-19 pandemic.

\section{About the author}

Dr Kamila AMMOUR is a senior lecturer at the department of English, Mouloud Mammeri University of Tizi-Ouzou. Her teaching areas include research methodology, academic writing, general linguistics, applied linguistics, phonetics, sociolinguistics, and ELT. She is now investigating issues pertaining to English Language Teaching and Critical Discourse Analysis.

ID ORCID: https://orcid.org/0000-0001-7100-7291

\section{References}

Anderson, N. J. (1991). Individual differences in strategy use in second language reading and testing. The Modern Language Journal, 75(4). 460-472. DOI: 10.2307/329495

Anderson, N. J. (1999). Exploring second language reading: Issues and strategies. Boston, MA: Heinle \& Heinle.

Bell, J. (1987). Doing your research project. Philadelphia: Open University Press

Benkhider, N., \& Kherbachi, S. (2020). The influence of remote learning on students' learning habits during covid-19. Les Cahiers du Cread, 36 (3). 425-448.

Birch, B. M. (2002). English L2 reading: Getting to the bottom. Mahwah, NJ: Lawrence Erlbaum Associates, Inc.

Brown, D. (2001). Teaching by principles: An interactive approach to language pedagogy. Michigan: Michigan University.

Carrell, P. (1998). Can reading strategies be taught? The Language Teacher, 22(3), 7-14.

Carrell, P., Devine, J., \& Eskey, D. (1988) Interactive approaches to second language reading. Cambridge: Cambridge University Press. 
Arab World English Journal (AWEJ) Special Issue on Covid 19 Challenges April 2021

Chelghoum, A., \& Chelghoum, H. (2020). The Covid-19 Pandemic and Education: Big Changes ahead for Teaching in Algeria. ALTRALANG Journal, 2 (2). 118-132.

Davies, F. (1995). Introducing reading. London: Penguin Books.

Emerald, D. V. (1991). Understanding and teaching reading: An interactive model. Hillsdale, NJ: L. Erlbaum Associates.

Goodman, K. S. (1970). Reading: a psycholinguistic guessing game. In H. Singer \& R. B. Ruddell (Ed.), Theoretical models and processes of reading. Newark, DE: International Reading Association.

Hudson, T. (2007). Teaching second language reading. Oxford: Oxford University Press.

Hutchinson, T., \& Waters, A. (1987). English for specific purposes. Cambridge: Cambridge University Press.

Kucer, S. B. (2005). Dimensions of literacy: A conceptual base for teaching reading and writing in school settings. Mahwah, NJ: Lawrence Erlbaum Associates.

Mayring, P. (2014). Qualitative content analysis theoretical foundation, basic procedures and software solution. Retrieved from [http://nbn-resolving.de/urn:nbn:de:0168-ssoar395173].

Pressley, M. (2002). Effective beginning reading instruction. Journal of Literacy Research. DOI: $10.1207 / \mathrm{s} 15548430 \mathrm{j} 1 \mathrm{r} 3402 \_3$

Smith, F. (1971). Understanding reading. New York: Holt, Rinehart and Winston.

Wallas, C. (1992). Reading. London: Oxford University Press.

\section{Appendices}

Appendix A

\section{Classroom Observation Scheme}

- The teaching procedure:

Activating learners' background knowledge

-Pre-reading phase:

Setting a purpose for reading

Pre-teaching unknown vocabulary

Word attack strategies

Comprehension and interpretation strategies

-While reading phase:

Comprehension questions

-Post-reading phase

- The Classroom environment: Learners' habits.

\section{Appendix B}

\section{Teachers' Interview}

1. What is the objective of reading classes at the elementary level?

2. What are the difficulties you encounter while teaching reading strategies?

3. How do you perceive reading strategies instruction?

4. How can you describe your learners during the Covid-19 pandemic?

5. What are the teaching/learning conditions you think are more impacted by the spread of the Covid-19 pandemic? 